\title{
The Role of Recreational Sport Toward the Development of Sport Tourism in Indonesia in Increasing the Nations Quality of Life
}

\author{
Sabaruddin Yunis Bangun ${ }^{1}$ \\ ${ }^{1}$ Universitas Negeri Medan, Medan, Indonesia \\ Correspondence: Sabaruddin Yunis Bangun, Universitas Negeri Medan, Medan, Indonesia. E-mail: \\ unisbgn@gmail.com
}

Received: January 16, 2014

Accepted: February 20, 2014 Online Published: February 28, 2014

doi:10.5539/ass.v10n5p98

URL: http://dx.doi.org/10.5539/ass.v10n5p98

\begin{abstract}
Sport tourism or tourism in sport is a new paradigm in the tourism and sport development in Indonesia. Sport tourism development requires qualified and reliable human resources in designing various kinds of sport activities so that they will become saleable tourism attractions because they possess economic values and become profitable for the country or an area. Tourism and sport are the spearhead of future life which are able to elevate our nation's dignity in front of other nations of the world. Tourism and sport together with other related activities can trigger new businesses, services and new products. The objective of this article is to explore and explain how will the development of sport tourism in Indonesia through recreational sport be able to increase the life quality of the nation. Hence the coordination and support from all agencies (Government Agencies, College, Main and Branch of Sport Organization, Businessman, Non-Governmental Organization, and Other Community Organization) are required in advancing sport tourism in Indonesia. Sport tourism promotion should cover all activities so that it will orientate on the importance and success. For example conferences, sport and tourism exhibition, recreational sport show, and traditional sport.
\end{abstract}

Keywords: recreational sport, sport tourism, quality of life

\section{Introduction}

Sport and tourism are two disciplines that can be integrated so that it has the power and double the effect on economic growth in Indonesia. Therefore sport tourism is currently receiving great attention from government, private sector, the sports industry, tourism industry, academia and society.

The question is how sport can be attributed to tourism or in other words, how sport can be presented as a tourist attraction that sport tourism industry that generates revenue in order to improve the quality of life for people in the future? Sport Tourism or tourism for sport is a new paradigm in the development of tourism and sports in Indonesia.

This paradigm has emerged previously evidenced by the issue of an international journal "Sport Tourism" and teaching training in "Sport Recreation" at the Faculty of Sport in Indonesia for example at Universitas Negeri Medan which includes recreational sports courses into the curriculum which is compulsory for students of Physical Education, Sports and Recreation. This becomes very important because the development of sports tourism human resource demands superior and reliable individuals to design various kinds of sports activities so that it becomes commercially viable tourist attraction because it has economic values and generates revenue for the country or a region.

Development of sport and tourism in Indonesia today is a demand and consideration must be given to ensure that the supply are available in times of increased demand or request. In Indonesia, activities such as diving, or commonly known as sport diving is beneficial not only to the health, but also for tourism, specifically marine tourism. Sport or Scuba diving in Indonesia is a maritime exercise that became a prime mover in the development of tourism. There are many other types of recreational sports can be explored in the development of sport tourism in Indonesia such as surfing, outbound activities, paragliding, traditional sports, equestrian, traditional wrestling, white water rafting, and rock climbing.

Sport is a medium that provides opportunities for graduates in sports and other related field to explore. Sports are replacing the role and eliminate destructive culture. Tourism is an activity and will also provide the opportunity 
for people to move, see, learn, and socialize; know the culture and the environment.

Organization of tourism and sport will develop with the progress and development of science and technology today. Tourism and sports will also promote the progress of science and technology. Tourism and sport is the subject and object as well as a very promising future for Indonesia if it can be extracted and utilized.

Tourism and sport are spearheading the future life, which can elevate this nation before the eyes of the world. Tourism and sports as well as other related activities can spark new businesses, services and new products. This is because of the importance and usefulness of tourism and sports as well as its association with the progress of other fields. Coordination and support from all stakeholders (Government Agencies, Universities, mains and branches of sports organizations, businesses, NGOs and other organizations) are required. Promotion of sports tourism activities should include all parties available so it is oriented to the interests and success of all. Activities should be organied for the benefit of all. Such activities include conferences, sports tourism exhibitions, special events, museums, architecture, sports performances, arts, traditional sports, and tourism itself.

The purpose of this article is to explore and explain how the development of tourism in Indonesian sport through recreational sports will be able to improve the quality of life of the nation. Analysis on how through recreational sports can affect the flow of tourism development in Indonesia and recommendations on the aspects that need to be done in the sport of tourism development in Indonesia, will also be discussed.

This article is an initial reference for:

1) Students of sport and tourism in the development of human resources as well as research in the field of sports tourism, physical education teachers and sports, lecturers at the Faculty of Sport Sciences and sports practitioners.

2) Become a reference material for sports services in an effort to improve the quality of its products as a tourist attraction that has international standards.

3) An input for the government, the Department of Tourism, Department of Youth and Sports, the National Sports Committee and other relevant agencies in planning the development of sports tourism in Indonesia.

\section{The Essence in Recreational Sports}

Constitution of the National Sports System 2005, Article 19 states that (1) Recreational Sports as part of the recovery process to gain health and fitness. (2) Recreational Sports can be executed by any person, educational unit, agency, association, or sports organization. (3) Recreational Sports aims to obtain health, physical fitness, and joy, build social relationships, and / or preserve and enhance the cultural richness of a region and nationally. (4) The Government, local government, and society are obliged to explore, develop, and promote recreational sports. (5) Any person who organizes recreational sports that involve risks specific to environmental sustainability, preservation of facilities, as well as the safety and health must comply with the provisions and procedures established in accordance with the type of sport, and provide instructors or guides who have the knowledge and skills appropriate to the type of sport. (6) Sports recreation shall meet the requirements set by the association or sports organization.

Recreational sports objectives are (1) the development of recreational sports are implemented and directed to develop the sport in an effort to increase public awareness of health, fitness, happiness, and social relationships. (2) Construction and development carried out by the Government, local government, and / or communities to build and exploit the potential of resources, infrastructure and recreational sports facilities. (3) The development of traditional leisure sports shall be reintroducedfor it to be beneficial for the society. (5) Development and implement the growth of recreational sports in a community, based on the principle of easy, inexpensive, attractive, beneficial, and volume. (6) The development of recreational sports conducted in an effort to develop studios and enable sports clubs in the community, as well as organizing sports festival at sustainable recreational level.

Recreation is usually done when a person has spare time, when he is free from work or duties, after the day-to-day needs are met. Webster's dictionary defines recreation as "a means to laid back or entertainment". Recreation should be enjoyable, fun, and involves almost no cost. Recreation recovers the body, mind, and rejuvenates the soul.

Precisely, the definition of recreation is "an activity or volunteered experience that a person does in his spare time, which provides personal satisfaction and enjoyment." Meyer, Brightbill, and Sessoms (2005) give nine basic characteristics of recreation, namely: i. an activity; ii. the form can be varied; iii. is determined by motivation; iv. done routinely; v. is completely voluntary; vi. is done universally and necessary; vii. is serious 
and useful; viii. is flexible; ix. is a byproduct. Recreation for children varies greatly according to the interests, needs, and abilities of each child. The people who lead recreational activities for children should recognize this diversity and not force any child to participate in the same program. Since recreation aims to refresh, build, and form experiences that are fun and valuable, the interest of each individual is important. So according to some theories, it can be concluded that recreational sport is a sport that is done by people with a penchant and ability to grow and develop in accordance with the conditions and cultural values of the local community for health, fitness, and enjoyment done in their spare time.

\section{Essence of Tourism}

Tourism is an activity to travel with the aim of getting pleasure, find satisfaction, learn something, improve health, enjoying sports or resting, perform tasks and make pilgrimages.

Travelers are people who travel from place of residence to visit other places and enjoy doing so. Spillanne (1987) divides the 6 types of tourism, namely: i. enjoy the trip; ii. recreation; iii. culture; iv. sports; v. trade and business; and, vi. conventions.

Indonesian tourism development is a key strategy for accelerated development in the area considering the potential resources of the nation which can contribute to Indonesian economic growth. When viewed by sector, Indonesia's economic growth of $4.86 \%$ has been mostly supported by agriculture, services, construction, transportation / communication, trade / hotel and restaurant, which means the growth of other sectors such as mining, manufacturing and financial is relatively small. Therefore, to create a spectacular growth of economic activity in Indonesia, the Government cannot rely on the economic sectors (which can be said to be relatively stagnant). It requires that a program driven by a sector which is considered to be the the stimulant of economic activity.

In this case the tourism sector believed to be the main driving force is appropriate given that Indonesian region has a huge potential as tourist destination areas. Tourism sector is said to be the main driving force because of the various studies and observations indicate that the tourism sector as a multiplier effects are great for all sectors of economic activity, both in the form of increased activity in terms of production and labor requirements.

Therefore, infrastructure to support tourism need to be improved. The Indonesian government will make Kuala Namu Airport and Belawan port as a main hub in North West Tourism Indonesia which connects Malaysia, Singapore, Sri Lanka, Vietnam, South Asia, Japan, Korea, Hongkong and Taiwan which share marine-based tourist attractions and culture.

\section{Sports Tourism Development}

Sport and tourism are the two disciplines that can be integrated so that it has the power and double the effect of economic growth in Indonesia in general. Therefore sport tourism is currently receiving great attention from government, private sector, the sports industry, tourism industry, academia and society. Sport ourism or tourism through sport is a new paradigm in the development of tourism and sports in Indonesia.

Sports tourism is able to demonstrate its potential as something of interest, so as to create a tourist attraction that caters for multicultural tourism. Tourist attractions are all things that exist in a region that is a tourist destination attraction that people increasingly have a greater interest to visit. So a tourist destination which has the appeal of a destination area should also have some requirements such as the existence of something that can be seen, there is an activity that will be done, and, the existence of something that can be purchased. This requirement isvery important because the development of sports tourism human resources requires superior design and reliable in a wide range of sporting activities so that it becomes a commercially viable tourist attraction because it has economic values and generates revenue for a country or region. Development of sport tourism in Indonesia today is a demand that must consider the supply to be available on demand or when demand increases.

Act 3 of 2005 of the Republic of Indonesia on National Sports System states that recreational sport is a sport that is done by people with a penchant and ability to grow and develop in accordance with the condition and value of local culture to promote health, fitness and enjoyment. In this case the sport and tourism have the same goal. If exercise aims to provide fun, tourism is an activity undertaken for pleasure. Sport tourism according to Spillane (1987) can be divided into two categories, namely:

1) Big sport events are major sporting events like the Olympic Games, world skiing championships, world championship boxing and other sports that interest not only in itself but also its athletes and thousands of spectators or fans.

2) Sporting tourism is tourism practicioners of the sport for those who want to do it such as mountain climbing, horse riding sports, hunting, and fishing. 
Based on the definition above sport tourism is aim for people who wants to see or watch a sporting event at a particular place or. Tourism aims to meet the satisfaction of the favored sports activities such as fishing, hunting, deep sea diving, skiing, hiking, and boating. In almost all parts of the world, sports tourism is increasingly developing and now many sports are being used as objects of attraction for tourists, especially in sports that use the facilities that are natural such as mountains, lakes, rivers, the sea and offers the charm of natural beauty.

Sport tourism is a blend of sport, recreation and tourism which is currently growing rapidly and in great demand among young travelers. Young travelers coming to Indonesia, among others, wants adventure and natural challenges through sport tourism. Indonesia's potential for sports tourism is huge and is good for activities including sport aviation (air), marine (sea) and land, such as mountain climbing and whitewater rafting or river canoeing.

The Ministry of Culture and Tourism has put sports tourism program as one of the tourism product that continues to be developed significantly, together with various agencies such as the Ministry of Youth, Sports Committee and sports federations across the country. Water sports practitioners lately enjoy doing so in Indonesia, proven by the number of visits to places of nautical tourism service providers every school holidays, long weekends, or the end of the year holidays. Water and adventure sport today has developed several attractions that are becoming known at locally and abroad such as boats, jet skis, air bikes, ski boats, swimming, water balls, paddling / kayak and white water rafting.

Development of water and adventure sport gets very good response and gets full support as a platform for entertainment or sports matches held to provide entertainment to the public. Water and adventure sport area, is a natural tourist attraction, combined with artificial tourism (recreation) with professional management will help increase the economy.

Sport tourism is a growing subject because it brings a positive effect on other sectors. Deery, Jago \& Fredline (2004) states that sport tourism has become the subject of an increasing level of both academic and government interest. It is perceived to be important Because of its economic contribution as well as other influences such as the impact on community well-being and the sense of pride that sport tourism may provide. Gibson (2005) explains that the development of sports tourism includes paradigms used in sports and tourism studies, those of tourist roles, destination branding, seasonality, and host-guest relations.

For further development of sports tourism, there is a need to improve the quality of all aspects as Robinson and Gammon (2004) states that a sport tourism framework is detailed and not only illustrates a tentative sport tourist typology but also a method which organisations can utilise, in order to identify current and future sport tourism developments.

\section{Discussion}

The sea surrounding Indonesia is a source of natural wealth which can also be used as potential tourist attraction areas which can contribute to the economy. Sport tourism is a basic requirement in the development of tourism in Indonesia, because it is a kind of nautical sports sectors which have significant contribution to the Indonesian economy and have a reliable prospect to be featured marine tourism sector.

Some indicators show that growth is quite significant for maritime activities that justify the importance accelerating the marine sector for tourism in Indonesian. Indications are shown from increase in growth maritime activities, and the growth in the number of foreign and local tourist involving in such activities between 2005 and 2010. This makes sports tourism becoming salient, thus making the role of leisure in social life more important. The role of leisure in social life can be classified as follows:

1) Develop a sense of respect, love and preservation of the environment.

2) Develop understanding and skills as well as an understanding of the importance of maintaining environmental balance and use them wisely.

3) Raise awareness of the importance of fostering human interrelationships between humans and environment.

4) Help develop positive behavior and social relationships.

5) Help develop the science of sound environmental practices.

6) Help make classroom lessons become more meaningful through direct experience in the field.

7) Opportunities to build cooperation among the school community with recreation service organizations in particular and society in general.

8) Foster and strengthen self-confidence and self-esteem which is a strong foundation for "self concept". 
9) Strengthen the brotherhood and the growth of mutual support among group members.

10) Augment or enhance the skills and coordination.

11) Add a personal pleasure and a sense of community among the members of the group.

12) Educate someone to be able to fill his spare time with positive activities, not harming himself, others, or the environment and preventing the emergence of negative activities, such as drug use, vandalism, and other similar negative activities.

13) Develop a culture of healthy living, both for personal and for others and or the natural environment.

The development of sports tourism can provide great benefits to the government in terms of:

1) Improving the economy of local community

2) Increase the tourist potential areas

3) Sharing information with people to stimulate active participation

4) Improve cooperation between national and local governments in controlling tourist attractions

5) Develop and find new attractions to enhance existing attractions

6) Increase employment opportunities for local community sports and recreation human resources.

7) Improve products and local marketing in all aspects of tourism

8) Introducing various types of local culture, enriching government insights and traditional sports tourist attractions.

Operating sports tourism locally can also provide benefits to the surrounding community because it can open up business opportunities such as the provision of food, drink, and transportation businesses. With the opening of business opportunity positive interaction between communities and the attractions so as to give rise to a sense of belonging and to participate actively in regional security, orderliness, cleanliness, provision of infrastructure, accommodation, souvenirs, and guide services.

Sports tourism development will also benefit the following areas:

1) Tourism will increase revenues and strengthen the balance of payments, increased tax revenues from the sector, stimulating the growth of other economic sectors, such as agriculture, stockbreeding, light industry, decoration, art and craft creations which are all interrelated and mutually supportive.

2) Expanding the social values of life and knowledge, media relations between tourism where the tourists interacts with the community and bring a new outlook on life and foster personal values of its own. Thus the growing sense of friendship, tolerance, mutual respect, unity and integrity is enhanced.

3) Most of the tourists who come to visit an area or region with a view to enjoy and admire the culture of the original creation, encourages the development of creative tourism. Besides it will also increase the income of local people, which in turn will increase efforts to improve the quality crafts.

4) Domestic tourism fosters national unity because of the growing sense of love of country and the nation itself. The introduction of a national culture will foster a sense of personal pride to the nation itself.

5) Travelers always wanted to visit places that they deem convenient, cool, beautiful and genuine. This encourages the maintenance of the natural environment that can satisfy the tastes of the tourists. The logical consequence of the development of tourism is a growing need for a means of tourism and the tourism industry. The tourism industry is centred on providing the best service possible. Therefore, the development of the tourism industry will absorb a lot of manpower at all levels to fill the job opportunities available in the industry.

6) Event tourism will release the tension for the physical and spiritual. Thus will foster good health. This will release tension helped improve work performance and good life in society.

\section{Conclusion}

The role of recreational sports in sports tourism development in Indonesia in improving the nations quality of life apparently has a big impact if the management system is well laid out. Sport and tourism are the two disciplines that can be integrated so that it has the power and double the effect on economic growth in Indonesia in general. Therefore sport tourism is currently receiving great attention from government, private sector, the sports industry, tourism industry, academia and society. Sport tourism or tourism through sport is a new paradigm in the development of tourism and sports in Indonesia. 
Sport tourism is a blend of sport and recreation which is currently growing rapidly and in great demand among young travelers. Young travelers comes to Indonesia, among others, wants adventure and natural challenges in sport tourism. Indonesia's potential for sports tourism is huge and good for sports such as aviation (air), marine (sea) and land, such as mountain climbing and whitewater rafting or river canoeing.

The coordination and support of all stakeholders (government agencies, universities, sports organizations, businesses, NGOs and other organizations) are indispensable in advancing sport tourism in Indonesia. Promotion of sports tourism activities should include all facilities available and focus on the interests and success for all.

\section{Recommendation}

1) Government should have a strong commitment to promote sports tourism in Indonesia in order to increase the quality of life of the nation.

2) Government must be able to decentralize the power to experts and scholars in this area as well as to provide transparency in the use of budget.

3) Government should add sport tourism to the existing curriculum at the Faculty of Sport Science in Indonesia to provide potential human resource.

4) Government should focus on human resource development through the standards of science and technology and is certified to conduct sports tourism activities.

5) Government should focus on correcting and adding infrastructure to support sports tourism.

6) Government should focus on recreational sports to combat social problems.

7) Government should focus on the improvement and development of sports and sports business industry in order not to depend on other countries, so there are opportunities for the employment of Indonesian society.

8) Government should benchmark sport tourism in developed countries and in implements it in Indonesia by using the effective and efficient management.

9) Optimization of institutional empowerment of sport with relevant institutions with the aim of developing and increasing the quality of sports.

\section{References}

Deery, M., Jago, L. K., \& Fredline, L. (2004, August). Sport tourism or event tourism: are they one and the same? Journal of Sport Tourism, 9(3). http://dx.doi.org/10.1080/1477508042000320250

Gibson, H. (2005, June). Sport Tourism: Concepts and Theories: An Introduction. Journal of Sport Tourism, 8(2).

Negara Republik Indonesia, Undang-Undang Tentang Sistem Keolahragaan Nasional, Nomor 3 Tahun 2005.

Robinson, T., \& Gammon, S. (2004, August). A question of primary and secondary motives: Revisiting and applying the sport tourism framework. Journal of Sport Tourism, 9(3). http://dx.doi.org/10.1080/1477508042000320223

Spillane, J. (1987). Ekonomi Pariwisata, Sejarah dan Prospeknya. Penerbit Kanisius, Yogyakarta.

\section{Copyrights}

Copyright for this article is retained by the author(s), with first publication rights granted to the journal.

This is an open-access article distributed under the terms and conditions of the Creative Commons Attribution license (http://creativecommons.org/licenses/by/3.0/). 